\section{Oral Health-Related Quality Of Life of Pre-School Children: Review and Perspectives for New Instruments}

\author{
Matheus França Perazzo ${ }^{10}$, Paulo Antônio Martins-Júnior ${ }^{10}$, Lucas Guimarães \\ Abreu $^{1 \mathbb{D}}$, Flávio Freitas Mattos ${ }^{2}$, Isabela Almeida Pordeus ${ }^{1 \mathbb{D}}$, Saul Martins
} Paiva $^{1}$ (D)

\begin{abstract}
This study aimed to describe different approaches for the evaluation of the Oral healthrelated quality of life (OHROoL) of preschool children and to discuss perspectives for future instruments. The $\mathrm{OHROOL}$ is a concept that surpasses an exclusively clinical perception and includes functional, social, emotional, and environmental issues. The measure of $\mathrm{OHROoL}$ represents a holistic approach for researchers and clinicians extending their visions beyond the mouth and understanding the entire context of the patient. Negative impacts of oral conditions on OHRQoL in childhood can reflect on health development, especially in a life stage marked by social and cognitive maturation. Instruments have been developed and cross-culturally adapted to evaluate the impact of oral conditions on the OHROoL of preschool children and their families. Some features distinguish these instruments and influence their selection, such as: self- or proxy-report; generic- or specific-condition; long- or short-form, and less or more established used in literature. Moreover, theoretical framework, construct validation and availability should also be considered. Nine OHROoL instruments for preschool children were included in the present literature review. They were created between 2003 and 2017 by developed countries in most cases. The shorter instrument has five items, and the larger has 31 items. Most of them are proxy-reported, generic-condition, and have been relatively well established in the literature. The diversity of instruments indicates the evolution of OHROoL studies, but there are methodological issues still in need to be improved in future developments or cross-cultural adaptations, according to current psychometric evidence.
\end{abstract}

ISSN 0103-6440

'Department of Paediatric Dentistry, UFMG - Universidade Federal de Minas Gerais, Belo Horizonte, MG, Brazil

${ }^{2}$ Department of Social and Preventive Dentistry, UFMG Universidade Federal de Minas Gerais, Belo Horizonte, MG, Brazil

Correspondence: Saul Martins Paiva, Avenida Antônio Carlos, 6627, 31.270-901 Belo Horizonte, MG, Brasil, Belo Horizonte, MG, Brasil. Tel: +55-31-3409-2470. e-mail: smpaiva@uol.com.br

\section{Introduction}

Oral health-related quality of life (OHROoL) is a multidimensional construct concerning the subjective self-perception of how oral health can impact individuals' functional and emotional well-being, as well as expectations and satisfaction with care (1). Briefly, OHRQoL refers to the extent to which individuals' oral health affects their wellbeing and ability to perform daily activities (2). It is a complex and dynamic construct, subject to change over time and according to social, cultural or political contexts (1). Since cognitive and social relationships are in maturation during early childhood, oral health issues may have a negative impact on the OHROoL of preschoolers ( 3 to 5 years of age) with far-reaching detrimental consequences on the short- and long-term $(3,4)$. Nevertheless, the prevalence of dental caries in young children has not decreased over the past decade, despite improvements for older children. Therefore, instruments to measure OHROoL have been developed and cross-culturally adapted with a particular focus on this age group $(4,5)$. In this sense, the modification and management of factors that may negatively interfere in the lives of preschool children become feasible.

OHROoL instruments must respect the inherent characteristics and limitations of their target population (6). Different from older age groups, preschoolers have lower levels of formal education, autonomy (including independence to attend appointments with the dentist), and understanding of the health-disease process, as well as limited ability to retrieve information on past events. Accordingly, parents/caregivers may act as proxies for their sons/daughters during the measure of preschool children's OHRQoL $(4,5)$. Dentists with a holistic approach in oral health find in these instruments powerful support to assess the impact of oral conditions on the life of their young patients and their families. The use of quality of life measures in clinical practice may improve communication between dentist, child, and parent/caregiver $(7,8)$. They may be helpful in the clinical decision-making process, weighing risks, benefits and treatment costs. Besides, those measures can assist in resources allocation, public health programs design, care prioritization and observation of changes/ responses to treatment $(7,9)$.

Despite the importance to evaluate OHROoL in preschool children, the development of instruments for this age group has come later in comparison to tools aiming to assess the OHRQoL of adolescents and adults. 
Methodological and conceptual challenges for developing OHROoL instruments for very young individuals are reasons for such delay (10). The aim of the present study is two-fold: to critically review instruments adopted for the evaluation of preschool children's OHRQoL and to provide insights about perspectives for the development and cross-cultural adaptation of new instruments.

\section{OHROoL Instruments for Preschool Children}

Some of the most usual OHROoL instruments for preschool children are reviewed, focusing on their definitions, applications and peculiarities. The searching was conducted at Web of Science, Medline (PubMed) and Scopus. The keywords used for data collection were oral health, quality of life, validation study, surveys and questionnaires, preschool child, and psychometrics. No restrictions to period of time or language were applied.

\section{Michigan Oral Health-related Quality of Life Scale}

Authors/Year: Filstrup et al., 2003 (11)

Abbreviation: Michigan OHRQoL Scale

Country: United States of America

Age group: 4 years and older

Respondent: Preschool children, school children and parents/caregivers

Versions: Child version and Parent/Caregiver version

Total items: 9 (Child version) and 10 (Parent/Caregiver)

Cross-cultural adaptation: Table 1

The Michigan Oral Health-related Quality of Life Scale (Michigan OHROoL Scale) was the first questionnaire developed to evaluate the OHROL of young children using both parent and child self-reports. It presents two versions: child and parent/guardian. The former comprises nine items with a dichotomic response scale (yes or not), and the later comprises ten items with a 5-point Likert response scale (11). However, the Michigan OHROoL Scale has some features that limited your use and adherence. Firstly, its items work as independent questions, rather than as one measure. Secondly, there is insufficient concrete evidence of the questions' psychometric properties. Moreover, the instrument was not developed to be used in epidemiological studies, but in clinical settings. In the original paper, the criteria used to evaluate whether a child was able to answer the questionnaire presented a poor psychological framework $(4,5)$. In an attempt to verify this specific child's ability, he/she should answer the following questions meaningfully: "Are you a boy or a girl?" and "What does a dentist clean and fix?" (11). Despite the limitations, this instrument was a fundamental step for the development of other instruments to measure the OHRQoL of preschool children $(4,5)$.

\section{Early Childhood Oral Health Impact Scale}

Authors/Year: Pahel et al., 2007 (5)

Abbreviation: ECOHIS

Country: United States of America

Age group: 3-5 years

Respondent: Parents/caregivers

Total items: 13

Sections: Child Impact and Family Impact

Subscales: Child Impact section - symptoms (1 item), function (4 items), psychology (2 items) and self-image/ social interaction ( 2 items). Family Impact section - parental distress ( 2 items) and family function ( 2 items)

Cross-cultural adaptation: Table 2

The Early Childhood Oral Health Impact Scale (ECOHIS) was the first questionnaire developed to specifically assess the OHRQoL in young children group and their families $(5,13,14)$. Contrasting, the content validity of Michigan OHROoL Scale is not specific to preschool age group, and this instrument also does not evaluate the family impact (11). Although it had been originally validated for 3 to 5 year-old-children, some cross-cultural adaptations have extended this age range, and versions for children between 0 to 6 years of age have been developed $(15,16)$. This questionnaire comprises 13 items distributed across six dimensions and two sections. Both sections are answered by parents/caregivers (proxy report). The ECOHIS can be selfadministered or administered as face-to-face interviews or telephone interviews. For purposes of reliability, the same method should be used from the beginning to the end of the study (17).

Aself-reportquestionnaire is the primary method for assessing health-related quality of life (18). However, self-report instruments can be limited when investigating OHRQoL of pre-schoolers. There is reasoning for the adoption of the proxyreport approach in ECOHIS:
Table 1. Descriptive and measurement properties of cross-cultural adaptations of Michigan OHRQoL Scale

\begin{tabular}{|c|c|c|c|c|c|}
\hline \multirow{2}{*}{ Country - Language } & \multirow{2}{*}{$\mathrm{N}$} & \multirow{2}{*}{$\begin{array}{c}\text { Female } \\
(\%)\end{array}$} & \multicolumn{3}{|c|}{ Measurement Proprieties } \\
\hline & & & Cronbach's $\alpha^{*}$ & $\begin{array}{l}\text { Test-retest } \\
\text { reliability }\end{array}$ & $\begin{array}{l}\text { Internal } \\
\text { structure }\end{array}$ \\
\hline $\begin{array}{l}\text { Saudi Arabia - Arabic } \\
\text { Language (12) }\end{array}$ & 120 & 70.0 & $\begin{array}{l}\text { Child version: } 0.64 \\
\text { Parent/Caregiver version: } 0.74\end{array}$ & NR & NR \\
\hline
\end{tabular}

*Cronbach's $\alpha$ for the global score. NR: non-reported. 
Table 2. Descriptive and measurement properties of cross-cultural adaptations of the ECOHIS

\begin{tabular}{|c|c|c|c|c|c|}
\hline \multirow{2}{*}{ Country - Language } & \multirow{2}{*}{$\mathrm{N}$} & \multirow{2}{*}{ Female (\%) } & \multicolumn{3}{|c|}{ Measurement Proprieties } \\
\hline & & & Cronbach's $\alpha^{*}$ & Test-retest reliability & Internal structure \\
\hline $\begin{array}{l}\text { Argentina and Venezuela } \\
\text { - Spanish (15) }\end{array}$ & $\begin{array}{l}142 \text { (Argentina) } \\
50 \text { (Venezuela) }\end{array}$ & NR & 0.87 (Argentina) & NR & NR \\
\hline Australia - English (34) & 273 & 40.3 & 0.87 & $\begin{array}{c}\mathrm{n}=33 \\
\mathrm{t}=14-21 \text { days } \\
\mathrm{ICC}=0.92\end{array}$ & NR \\
\hline Brazil - Portuguese (13) & 1643 & 48.7 & NR & $\begin{array}{c}n=228 \\
t=7 \text { days } \\
\text { ICC }=0.99\end{array}$ & NR \\
\hline Brazil - Portuguese (14) & 247 & 50.2 & 0.86 & $\begin{array}{c}n=49 \\
t=30 \text { days } \\
\text { ICC }=0.94\end{array}$ & NR \\
\hline Canada - French (35) & 398 & 53.1 & 0.82 & $\begin{array}{c}n=101 \\
t=14 \text { days } \\
\text { ICC }=0.95\end{array}$ & NR \\
\hline Chile - Spanish (36) & 302 & 46.0 & 0.89 & $\begin{array}{c}\mathrm{n}=151 \\
\mathrm{t}=14 \text { days- } \\
1 \text { month } \\
\text { ICC }=0.84\end{array}$ & NR \\
\hline China - Chinese (37) & 111 & 45.9 & 0.91 & $\begin{array}{c}n=21 \\
t=21 \text { days } \\
\text { ICC }=0.64\end{array}$ & NR \\
\hline Colombia - Spanish (38) & 643 & 48.2 & 0.87 & NR & NR \\
\hline India - Hindi (39) & 469 & 42.2 & 0.87 & $\begin{array}{c}\mathrm{n}=\mathrm{NR} \\
\mathrm{t}=1 \text { month } \\
\text { ICC }=0.91\end{array}$ & NR \\
\hline Iran - Farsi (40) & 246 & 57.0 & 0.93 & $\begin{array}{c}\mathrm{n}=82 \\
\mathrm{t}=14 \text { days } \\
\mathrm{ICC}=0.82\end{array}$ & NR \\
\hline Lithuania - Lithuanian (41) & 130 & 48.5 & 0.87 & $\begin{array}{c}\mathrm{n}=30 \\
\mathrm{t}=14 \text { days } \\
\mathrm{ICC}=0.98\end{array}$ & NR \\
\hline Malay - Malay (16) & 127 & 49.6 & 0.83 & $\begin{array}{c}n=25 \\
t=10 \text { days } \\
\text { ICC }=0.94\end{array}$ & NR \\
\hline Nigeria - Pidgin English (42) & 104 & 49.0 & 0.86 & $\begin{array}{c}n=50 \\
t=7 \text { days } \\
\text { ICC }=0.97\end{array}$ & NR \\
\hline Peru - Spanish (43) & 128 & 52.3 & 0.95 & $\begin{array}{c}\mathrm{n}=128 \\
\mathrm{t}=7 \text { days } \\
\mathrm{ICC}=0.99\end{array}$ & NR \\
\hline $\begin{array}{l}\text { Saudi Arabia - Arabic } \\
\text { language (44) }\end{array}$ & $\begin{array}{l}\text { Community-based } \\
\text { sample }=422 \\
\text { Clinic-based } \\
\text { sample }=246\end{array}$ & $\begin{array}{c}\text { Community-based } \\
\text { sample }=57.1 \\
\text { Clinic-based } \\
\text { sample }=52.4\end{array}$ & $\begin{array}{l}\text { Community- } \\
\text { based sample } \\
0.85\end{array}$ & $\begin{array}{l}\text { Clinic-based sample } \\
\qquad \mathrm{n}=68 \\
\mathrm{t}=14-21 \text { days } \\
\text { ICC }=0.86\end{array}$ & NR \\
\hline $\begin{array}{l}\text { Tanzania - Kiswahili } \\
\text { Uganda- Luganda (45) }\end{array}$ & $\begin{aligned} \text { Tanzania } & =1221 \\
\text { Uganda } & =816\end{aligned}$ & $\begin{array}{c}\text { Tanzania }=49.5 \\
\text { Uganda }=49.3\end{array}$ & $\begin{array}{l}\text { Uganda } \\
0.84\end{array}$ & $\begin{array}{c}\text { Uganda } \\
\text { Clinic-based sample } \\
n=24 \\
t=14 \text { days } \\
\text { ICC }=0.70\end{array}$ & NR \\
\hline Trinidad - English (46) & 251 & 88.0 & 0.94 & NR & NR \\
\hline Turkey - Turkish (47) & 121 & 53.7 & 0.93 & $\begin{array}{c}\mathrm{n}=30 \\
\mathrm{t}=21 \text { days } \\
\mathrm{ICC}=0.86\end{array}$ & NR \\
\hline
\end{tabular}

${ }^{*}$ Cronbach's $\alpha$ for the global score. NR: non-reported. ICC: Intraclass Correlation Coefficient. 
individual's abstract thinking ability is developed at about six years of age; preschool children would be unable to understand the items; children younger than six years of age would be unable to accurately recall both every day and unique events beyond $24 \mathrm{~h}(18,19)$. However, some of these justifications were critically re-evaluated by the authors of another instrument, the Scale of Oral Health Outcomes for 5-year-old children (SOHO-5), which is divided into self-reported and proxyreported versions $(4,20)$.

ECOHIS is the most used questionnaire to evaluate the impact of oral conditions on the OHRQoL of preschoolers and their families. The experience of early childhood caries (ECC) has shown a negative impact on the "symptoms", "function" and "psychological" domains of the Child Impact section as well as the "distress" domain of the Family Impact section. Other studies using ECOHIS have explored the impact of the following oral conditions on OHRQoL: traumatic dental injuries (TDI), malocclusion, sleep bruxism (21), toothache (22), oral mucosa conditions (23), fluorosis (24) and eruption hematoma (25). However, authors have suggested that ECOHIS is more suitable for assessing some oral conditions (i.e. ECC and TDI) rather than others (i.e. malocclusion) (26). Some oral conditions with peculiar signs and symptoms may need instruments with higher sensitivity to measure their impact on OHRQoL $(26,27)$. However, condition-specific OHRQoL instruments are not usual in preschool age group.

After dental treatment of ECC in Brazilian $(28,29)$ and Chinese (30) individuals, ECOHIS demonstrated adequate responsiveness and identified a significant improvement of the OHRQoL of preschool children. On the other hand, an Australian study found moderate responsiveness and suggested the development of further investigations on ECOHIS to measure treatment effects in primary care settings in this country (31). In Canada, the limited ability of the English version of ECOHIS to identify changes after treatment has been explained by the low levels of oral conditions of the study sample (32). Therefore, OHROoL instruments may present different psychometric properties in different populations and languages (33).

\section{Scale of Oral Health Outcomes for 5-Year-Old Children}

Authors/Year: Tsakos et al., 2012 (4)

Abbreviation: $\mathrm{SOHO}-5$

Country: United Kingdom

Age group: 5 years

Respondents: Preschool children and parents/caregivers

Total items: 7 each version

Versions: Child version (self-report) and parental/ caregiver version (proxy-report)
Items: Child version - refer to difficulties of eating, drinking, speaking, playing, sleeping, smiling (due to pain), and smiling (due to appearance). Parental/caregiver version - refer to difficulties of eating, speaking, playing, sleeping, smiling (due to pain), smiling (due to appearance), and affected self-confidence of the child.

Cross-cultural adaptation: Table 3

The Scale of Oral Health Outcomes for 5-year-old children (SOHO-5) was developed to assess the OHRQoL of young children through both self- and parental/caregiver reports $(4,48)$. SOHO-5 comprises two versions (child version and parental/caregiver version). Each version has seven items (4). The meaning of most items is similar in both versions, but there are differences in language and response scale: a 5- point Likert response scale was used in the parental/caregiver version and a 3- point Likert response scale was used in the child version. Studies have evaluated the impact of oral conditions on preschool children's OHROoL using SOHO-5: ECC, TDI, malocclusion and sleep bruxism $(8,49)$. In both versions of the instrument used for ECC, the item which assesses difficult eating cases has been the most impaired across studies $(8,49)$.

Although there are limitations for preschool children to self-report issues related to abstract domains, evidence shows that 4-6-year-old children can reliably report on more concrete domains of their general health and quality of life, such as pain and dysfunction. Moreover, parents/ caregivers may have incomplete knowledge about their children's health due to their work routine, social life, or the amount of time children stay at daycare facilities (50). However, the proxy measure by parents/guardians must be considered together with the self-report of children, since children may not be aware of issues concerning some psychosocial domains (8), or may have difficulty in understanding emotions that require greater cognitive development. Given that parental and child reports measure different realities, $\mathrm{SOHO}-5$ can evaluate both perspectives of the OHROoL of preschool children $(8,50)$. Indeed, the Michigan OHRQoLScale already evaluated the self-reported set of OHROoL in preschool children. However, those items were treated as independent questions, rather than a composite measure, without presenting robust evidence on the construct.

Comparisons between reports found that mothers can rate their pre-schoolers' $\mathrm{OHROoL}$ similarly to their children's self-reports, while fathers under-report the negative impact of oral conditions. The proxy-report should be given by the relative/caregiver who spends more with the child (51). Another study also found that the presence of parents/ caregivers did not influence children's responses. Overall, SOHO-5 has proven to be valid, reliable, reproducible, 
and responsive to change in cross-cultural adaptations. However, researchers and clinicians should be attentive when interpreting responses of low-income preschool children, since social context may influence the cognitive development of children (49).

\section{Parental-Caregiver Perceptions Questionnaire}

Authors/Year: Jokovic et al., 2003 (56)

Abbreviation: P-CPO and PPO

Country: Canada

Age group: Preschool children, school children and adolescents

Respondent: Parents/caregivers

Total items: 31

Domains: oral symptoms (6 items), functional limitations ( 8 items), emotional well-being ( 7 items), social well-being (10 items).

Cross-cultural adaptation: Table 4

The Parental-Caregiver Perceptions Questionnaire (P-CPO) is one of the instruments included in the Child Oral Health Quality of Life Questionnaire (COHOOL), developed to measure parents'/caregivers' perceptions of the impact of children's oral conditions on their OHRQoL in the previous three months. The questionnaire contains 31 items distributed across four domains: oral symptoms, functional limitations, emotional well-being, and social well-being. The P-CPO also has two global questions; one rating children's oral health (How would you rate the health of your child's teeth, lips, jaws and mouth?) and the other assesses the relationship between children's oral health and their overall well-being (How much is your child's overall well-being affected by the condition of his/her teeth, lips, jaws or mouth?) (56).

The P-CPO was designed to be analogous to the Child Perceptions Questionnaire (CPO), enabling the practitioner or the researcher to obtain supplemental information about children's OHRQoL. Alongside CPQ, it allows to investigate agreement between child and parent/caregiver (56). Although there is no specific validity of CPO for the preschool group, the short-form $\mathrm{CPO}_{11-14}$ appears to have a practical use in children between ages of 5 and 14 (57). However, further research with $\mathrm{CPO}_{11-14}$ in younger subjects is required to confirm these findings in samples with relatively high caries experience and low income $(49,57)$. Originally, the $P-C P O$ was not validated to embrace parents/caregivers of pre-schoolers, but researchers have been expanding the age range of this instrument $(58,59)$.

Short-forms of the P-CPQ, such as the 8-, 13- and 16item scales have been developed (60). The simple evaluation of the condition/problem due to the reduced number of items or domains, minimise the burden on the respondent and mitigate the chance of missing data. However, the questionnaire may have lower internal consistency when compared to the full version (58,61-63). Versions with 16

Table 3. Descriptive and measurement properties of cross-cultural adaptations of SOHO-5 Parental-Caregiver Perceptions Questionnaire

\begin{tabular}{|c|c|c|c|c|c|}
\hline \multirow{2}{*}{ Country - Language } & \multirow{2}{*}{$\mathrm{N}$} & \multirow{2}{*}{ Female $(\%)$} & \multicolumn{3}{|c|}{ Measurement Proprieties } \\
\hline & & & Cronbach's $\alpha^{*}$ & Test-retest reliability & Internal structure \\
\hline Brazil - Portuguese (48) & 193 & $45.1 \%$ & $\begin{array}{c}0.77 \text { (Child version) } \\
0.90 \text { (Parental version) }\end{array}$ & $\begin{array}{c}\mathrm{n}=159 \\
\mathrm{t}=7-14 \text { days } \\
\text { ICC }=0.92 \text { (Child version) } \\
0.98 \text { (Parental version) }\end{array}$ & NR \\
\hline $\begin{array}{l}\text { Dominican Republic } \\
\text { - Spanish (52) }\end{array}$ & 69 & $50.7 \%$ & 0.85 (Child version) & NR & $\begin{array}{c}\text { CFA } \\
\mathrm{CFI}=1.00 ; \mathrm{TLI}=1.00 ; \\
\mathrm{RMSEA}=0.00\end{array}$ \\
\hline China - Chinese (53) & 249 & $42.0 \%$ & $\begin{array}{c}0.71 \text { (Child version) } \\
0.82 \text { (Parental version) }\end{array}$ & $\begin{array}{c}\mathrm{n}=25 \text { (children) } \\
28 \text { (parents) } \\
\mathrm{t}=14 \text { days } \\
\text { ICC }=0.85 \text { (Child version) } \\
0.46 \text { (Parental version) }\end{array}$ & NR \\
\hline Indonesia - Indonesian (54) & 161 & $49.7 \%$ & $\begin{array}{c}0.89 \text { (Child version) } \\
0.86 \text { (Parental version) }\end{array}$ & $\begin{array}{c}\mathrm{n}=27 \\
\mathrm{t}=7-14 \text { days } \\
\text { ICC }=0.94 \text { (Child version) } \\
0.81 \text { (Parental version) }\end{array}$ & NR \\
\hline Iran - Persian (55) & 160 & $49.0 \%$ & $\begin{array}{c}0.82 \text { (Child version) } \\
0.67 \text { (Parental version) }\end{array}$ & $\begin{array}{c}\mathrm{n}=30 \\
\mathrm{t}=14 \text { days } \\
\mathrm{ICC}=0.80 \text { (Parental version) }\end{array}$ & NR \\
\hline
\end{tabular}

${ }^{*}$ Cronbach's $\alpha$ for the global score. NR: non-reported. CFA: Confirmatory Factor Analysis. CFI: Comparative Fit Index. ICC: Intraclass Correlation Coefficient. RMSEA: Root Mean Square Error of Approximation. TLI: Tucker-Lewis index. 
and 8 items scales have been the most used tools among all the P-CPO short-form versions $(60,63,64)$. The 13 -item scale developed in Brazil has three domains (oral symptoms, functional limitations and wellbeing) (65).

Most studies in preschool children use the P-CPO to assess changes in their OHROoL following dental treatment $(66,67)$. In general, the P-CPO is responsive to changes arising from treatment of very young children affected by ECC $(66,67)$, and is promising for dental health services (66). When P-CPO and ECOHIS are compared, the latter may suit better in epidemiological surveys rather than in health services research. Despite these differences, ECOHIS (Child Impact section) and P-CPO are very similar in their internal consistency reliability, cross-sectional construct validity and responsiveness (58).

Pediatric Quality of Life Inventory ${ }^{T M}$ Oral Health Scale Authors/Year: Steele et al., 2009 (75)

Abbreviation: PedsQLTM Oral Health Scale

Country: United States of America

Age group: 2-18 years

Respondent: Parents/caregivers and/or preschool

Table 4. Descriptive and measurement properties of cross-cultural adaptations of P-CPQ

\begin{tabular}{|c|c|c|c|c|c|}
\hline \multirow{2}{*}{ Country - Language } & \multirow{2}{*}{$\mathrm{N}$} & \multirow{2}{*}{ Female (\%) } & \multicolumn{3}{|c|}{ Measurement Proprieties } \\
\hline & & & Cronbach's $\alpha^{*}$ & Test-retest reliability & Internal structure \\
\hline $\begin{array}{l}\text { Brazil } \\
\text { (short-form) - Portuguese (62) }\end{array}$ & 702 & 58.1 & 0.82 & NR & $\begin{array}{c}\text { EFA and CFA } \\
\mathrm{GFI}=0.90 ; \mathrm{CFI}=0.90 ; \mathrm{TLI}=0.87 ; \\
\mathrm{AGFI}=0.85 ; \mathrm{SRMR}=0.07\end{array}$ \\
\hline $\begin{array}{l}\text { Brazil - Portuguese } \\
\text { (full version) (68) }\end{array}$ & 123 & NR & 0.84 & $\begin{array}{l}\mathrm{n}=53 \\
\mathrm{t}=21 \text { days } \\
\mathrm{ICC}=0.83\end{array}$ & NR \\
\hline $\begin{array}{l}\text { China - Chinese (full } \\
\text { version) (69) }\end{array}$ & 168 & NR & 0.82 & $\begin{array}{l}n=84 \\
t=14 \text { days } \\
\text { ICC }=0.83\end{array}$ & NR \\
\hline $\begin{array}{l}\text { France - French (full } \\
\text { version) (70) }\end{array}$ & 142 & 47.9 & 0.85 & $\begin{array}{l}\mathrm{n}=85 \\
\mathrm{t}=14 \text { days } \\
\mathrm{ICC}=0.88\end{array}$ & $\begin{array}{c}\text { EFA and PCFA } \\
\text { NFI }=0.837 ; \text { CFI }=0.939 ; \text { TLI }=0.889 ; \\
\text { RMSEA }=0.049 ; \text { SRMR }=0.036\end{array}$ \\
\hline $\begin{array}{l}\text { India (8-16- item short } \\
\text { form) - Telugu (64) }\end{array}$ & 1342 & 41.0 & $\begin{array}{l}0.84 \text { (16-item) } \\
0.71 \text { (8-item) }\end{array}$ & $\begin{array}{c}\mathrm{n}=161 \\
\mathrm{t}=14 \text { days } \\
\text { ICC }=0.81(16-\mathrm{item}) \\
0.82(8 \text {-item) }\end{array}$ & NR \\
\hline $\begin{array}{l}\text { New Zealand } \\
\text { (full-form, 8- and 16- item } \\
\text { short form) - English (60) }\end{array}$ & 352 & 46.3 & $\begin{array}{c}0.92 \text { (full-form) } \\
0.89 \text { (16-item) } \\
0.82(8 \text {-item) }\end{array}$ & NR & CFA \\
\hline $\begin{array}{l}\text { Oman (short-form - } 8 \\
\text { items) - Arabic (63) }\end{array}$ & 191 & 50.3 & 0.53 & NR & NR \\
\hline $\begin{array}{l}\text { Peru (full version) } \\
\text { - Spanish (71) }\end{array}$ & 200 & 54.0 & 0.84 & $\begin{array}{c}\mathrm{n}=200 \\
\mathrm{t}=7-14 \text { days } \\
\mathrm{ICC}=0.94\end{array}$ & NR \\
\hline $\begin{array}{l}\text { Sweden (short-form - } 16 \\
\text { items) - Swedish (72) }\end{array}$ & 247 & 53.0 & 0.77 & $\begin{array}{c}\mathrm{n}=32 \\
\mathrm{t}=14 \text { days }-1 \text { moth } \\
\text { ICC }=0.63\end{array}$ & NR \\
\hline UK (full version) - English (73) & 87 & NR & $0.86-0.93$ & $\begin{array}{c}\mathrm{n}=\mathrm{NR} \\
\mathrm{t}=14 \text { days } \\
\mathrm{ICC}=0.92-0.95\end{array}$ & NR \\
\hline $\begin{array}{l}\text { USA (full version) } \\
\text { - English (74) }\end{array}$ & 180 & NR & NR & $\begin{array}{l}\mathrm{n}=136 \\
\mathrm{t}=14 \text { days } \\
\mathrm{ICC}=0.84\end{array}$ & NR \\
\hline
\end{tabular}

* Cronbach's $\alpha$ for the global score. NR: non-reported. AGFI: Adjusted Goodness-of-Fit Index. CFA: Confirmatory Factor Analysis. CFI: Comparative Fit Index. EFA: Exploratory Factor Analysis. GFI: Goodness-of-fit index. ICC: Intraclass Correlation Coefficient. NFI: Normed Fit Index. PCFA: Partial confirmatory factor analysis. RMSEA: Root Mean Square Error of Approximation. SRMR: Standardised Root Mean Square Residual. TLI: Tucker-Lewis index. 
children/older children/adolescent

Versions: Child/adolescent self-report (for children 5 to 18) or Parent/caregiver-proxy report (for ages 2 to 18 years) Total items: 5

Items: Refer to pain in the teeth (2 items) and periodontal tissue (1 item) and observable changes in tooth structures (1 item) and periodontal tissue (1 item).

Cross-cultural adaptation: Table 5

The Pediatric Quality of Life Inventory ${ }^{\mathrm{TM}}$ Oral Health Scale (PedsOL ${ }^{\mathrm{TM}}$ Oral Health Scale) was developed in view of the criticisms of scholars for whom the assessment of oral health should be included in pediatric generic HROoL measurements (75). Therefore, the PedsQL ${ }^{\mathrm{TM}}$ Oral Health Scale is used along with a generic HROoL instrument [PedsOL ${ }^{\text {TM }}$ 4.0 Generic Core Scales - 23 items (76); PedsQL ${ }^{\mathrm{TM}} 4.0$ Generic Core Scales Short Form - 15 items (77)] or disease/condition-specific modules [PedsQL ${ }^{\mathrm{TM}} 3.0$ Cardiac Module - 27 items (78); Type 1 Diabetes Module - 28 items (79); Cancer Module - 27 items (80); Asthma Module - 28 items (81); Cerebral Palsy Module - 35 items (82)] to provide an overall measure of OHROoL. The Oral Health Scale contains five items in two parallel forms $\therefore$ for child self-report and parent proxy-report. Child and adolescent self-reports include ages 5-7, 8-12, and 13-18 years. Parent proxy-report includes ages 2-4 (toddler), 5-7 (young child), 8-12 (older child), and 13-18 (adolescent), assessing parental perceptions of their children's oral health. The forms are quite similar, differing in the use of age-specific language and the use of first or third person. A 5-point response scale is used in the child-, adolescent-, and parent proxy-reports. For the young child self-report (ages 5-7), response scale is simplified to a 3-point format, using three pictures (ranging from a happy face to a sad face) portraying response to the impacts.

The use of PedsQL ${ }^{\mathrm{TM}}$ Oral Health Scale in OHROoLstudies is not common in studies with preschool individuals. Some studies applied other instruments to evaluate OHROoL along with PedsQL ${ }^{\mathrm{TM}} 4.0$ Generic Core Scales, instead of using the PedsQL ${ }^{\mathrm{TM}}$ Oral Health Scale $(83,84)$. The low acceptability of PedsOL ${ }^{\mathrm{TM}} 4.0$ Generic Core Scales can be justified by the availability of other $\mathrm{OHROoL}$ questionnaires, previously validated. Cross-cultural adaptation of age group specific questionnaires has taken place in a limited number of countries. The Persian version of PedsOL ${ }^{\mathrm{TM}}$ Oral Health Scale, for instance, was not validated for preschool children (85).

\section{Pediatric Oral Health-Related Quality of Life \\ Authors/Year: Huntington et al., 2011 (88) \\ Abbreviation: POOL \\ Country: United States of America \\ Age group: 2-14 years \\ Respondent: Parents/caregivers, school-age, and pre- teen children}

Table 5. Descriptive and measurement properties of cross-cultural adaptations of PedsQL ${ }^{\mathrm{TM}}$ Oral Health Scale

\begin{tabular}{|c|c|c|c|c|c|}
\hline \multirow{2}{*}{$\begin{array}{l}\text { Country - } \\
\text { Language }\end{array}$} & \multirow{2}{*}{$\mathrm{N}$} & \multirow{2}{*}{$\begin{array}{c}\text { Female } \\
(\%)\end{array}$} & \multicolumn{3}{|c|}{ Measurement Proprieties } \\
\hline & & & Cronbach's $\alpha^{*}$ & Test-retest reliability & Internal structure \\
\hline $\begin{array}{l}\text { Brazil - } \\
\text { Portuguese (86) }\end{array}$ & $\begin{array}{l}208 \text { (proxy- } \\
\text { report and } \\
\text { self-report) }\end{array}$ & 58.7 & $\begin{array}{c}0.65 \text { (self-report) } \\
0.59 \text { (proxy-report) }\end{array}$ & $\begin{array}{c}\mathrm{n}=\mathrm{NR} \\
\mathrm{t}=14 \text { days } \\
\text { ICC }=0.90 \text { (self-report) } \\
0.86 \text { (proxy-report) }\end{array}$ & $\begin{array}{c}\text { CFA } \\
\text { Self-report } \\
\text { NFI }=0.98 ; \text { CFI }=1.00 \\
\text { GFI = 0.99; AGFI }=0.98 ; \text { RMSEA }=0.00 \\
\text { Proxy-report } \\
\text { NFI = 0.98; CFI }=1.00 ; \text { GFI }=0.99 ; \\
\text { AGFI }=0.97 ; \text { RMSEA }=0.00\end{array}$ \\
\hline $\begin{array}{l}\text { Chile - Spanish } \\
\text { (87) }\end{array}$ & $\begin{array}{l}301 \text { (proxy- } \\
\text { report) }\end{array}$ & 46.0 & 0.79 (proxy-report) & $\begin{array}{c}\mathrm{n}=84 \\
\mathrm{t}=14 \text { days- } 1 \text { month } \\
\mathrm{ICC}=0.86 \text { (proxy-report) }\end{array}$ & $\begin{array}{c}\text { CFA } \\
\text { Proxy-report } \\
\text { CFI = 0.996; TLI = 0.987; } \\
\text { RMSEA }=0.048\end{array}$ \\
\hline \multirow[t]{3}{*}{ Iran - Iranian (85) } & \multirow[t]{3}{*}{$\begin{array}{l}1,053 \text { (self- } \\
\text { report) } \\
1,026 \text { (proxy- } \\
\text { report) }\end{array}$} & \multirow[t]{3}{*}{58.0} & \multirow[t]{3}{*}{$\begin{array}{c}0.79 \text { (self-report) } \\
0.89 \text { (proxy-report) }\end{array}$} & \multirow[t]{3}{*}{$\begin{array}{c}\mathrm{n}=\mathrm{NR} \\
\mathrm{t}=1 \text { month } \\
\mathrm{ICC}=0.86 \text { (self-report) } \\
0.81 \text { (proxy-report) }\end{array}$} & $\begin{array}{c}\text { EFA and CFA } \\
\text { Self-report } \\
\text { GFI = } 0.99 ; \text { AGFI = } 0.98 ; \\
\text { NFI }=0.99 ; \text { CFI = } 0.99 ; \\
\text { RMSEA }=0.028 \\
\text { Proxy-report }\end{array}$ \\
\hline & & & & & $\begin{aligned} \text { GFI } & =0.99 ; \text { AGFI }=0.97 \\
\mathrm{NFI} & =0.99 ; \mathrm{CFI}=0.99 ;\end{aligned}$ \\
\hline & & & & & RMSEA $=0.052$ \\
\hline
\end{tabular}

${ }^{*}$ Cronbach's $\alpha$ for the global score. NR: non-reported. AGFI: Adjusted Goodness-of-Fit Index. CFA: Confirmatory Factor Analysis. CFI: Comparative Fit Index. EFA: Exploratory Factor Analysis. GFI: Goodness-of-fit index. ICC: Intraclass Correlation Coefficient. NFI: Normed Fit Index. PCFA: Partial confirmatory factor analysis. RMSEA: Root Mean Square Error of Approximation. TLI: Tucker-Lewis index. 
Total items: 10

Versions: Parent Report on Early Childhood, Parent Report on School-Age Child, Child Self Report on SchoolAge Child, Parent Report on Teen

Dimensions: physical functioning, role functioning, emotional functioning, and social functioning

Cross-cultural adaptation: Table 6

The POQL is a brief, internally consistent, valid, and reliable instrument for use in pre-school and school children, and pre-adolescents. There are equivalent parent report and child self-reported versions for children and preadolescents aged between 8 and 14 years. Originally, the POOL was developed in English and Spanish languages with a population in the Greater Boston area. The instrument was developed with emphasis on the experiences and views of a low income or minority population, representing an essential step in the accurate evaluation by individuals with high rates of oral disease. However, the authors of POOL state that it contains relevant items to both majority and minority populations, which allows the use of the questionnaire in a wide range perspective, including clinical assessments and large-scale population surveys (88).

The POQL versions are as follows: For children aged 2-7 years, there is only a proxy version (Parent Report on Early Childhood; PREC). For school children and pre-adolescents aged 8-14 years, there are two versions: a proxy one (Parent Report on School-Age Child; PRSC) and a version to children (Child Self Report - School Age; CSR). The POOL comprises ten items distributed across four domains: Physical Functioning ( 2 items), Role Functioning (2 items), Social Functioning ( 3 items) and Emotional Functioning ( 3 items). Although POQL presents a number of items similar to other instruments of $\mathrm{OHRO}$ oL for children, it highlights Social and Emotional Functioning domains: 60\% of items focus on socio-emotional impact, while other instruments focus $29 \%$

Table 6. Descriptive and measurement properties of cross-cultural adaptations of POQL

\begin{tabular}{|c|c|c|c|c|c|}
\hline \multirow{2}{*}{$\begin{array}{l}\text { Country - } \\
\text { Language }\end{array}$} & \multirow[b]{2}{*}{$\mathrm{N}$} & \multirow{2}{*}{$\begin{array}{c}\text { Female } \\
(\%)\end{array}$} & \multicolumn{3}{|c|}{ Measurement Proprieties } \\
\hline & & & Cronbach's $\alpha^{*}$ & $\begin{array}{l}\text { Test-retest } \\
\text { reliability }\end{array}$ & $\begin{array}{l}\text { Internal } \\
\text { structure }\end{array}$ \\
\hline $\begin{array}{l}\text { Turkey - } \\
\text { Turkish (89) }\end{array}$ & 149 & 46.7 & $\begin{array}{c}0.91 \text { (CSR) } \\
0.89 \text { (PRSC) }\end{array}$ & $\begin{array}{c}\mathrm{n}=16 \\
\mathrm{t}=14 \text { days } \\
\mathrm{ICC}=0.90(\mathrm{CSR}) \\
0.99(\mathrm{PREC})\end{array}$ & EFA \\
\hline $\begin{array}{l}\text { United States } \\
\text { - English (90) }\end{array}$ & 928 & 49.4 & 0.87 (PREC) & NR & EFA \\
\hline $\begin{array}{l}\text { United States } \\
\text { - Spanish (91) }\end{array}$ & 237 & 57.0 & 0.86 (PRSC) & NR & EFA \\
\hline
\end{tabular}

*Cronbach's $\alpha$ for the global score. NR: non-reported. CSR: Child Self Report. $\quad$ EFA: Exploratory Factor Analysis. ICC: Intraclass Correlation Coefficient. PREC: Parent Report on Early Childhood. PRSC: Parent Report on School-Age Child. to $44 \%$ of their items on the same subject. While social items in other measures are focused on personal interactions, the social items of POOL focus on appearance aspects. It results from the item-development technique applied, in which focus groups with children were conducted to capture their concerns and beliefs about oral health. At the time, children revealed a significant concern with appearance. Each question has two types of scoring and answers: (A) how often the event happened? Possible answers are: all of the time, some of the time, once in a while and did not happen; (B) how bothered was the child? Possible answers are: very bothered, somewhat bothered, never bothered, and did not happen. This strategy allows the researcher and/or clinician to measure and understand both the frequency of the event in the life of the child, and also how the event bothered him/her, enabling the identification of correlation between frequency and intensity (88).

\section{Caries Impacts and Experiences Questionnaire for Children}

Authors/Year: Gilchrist et al., 2018 (92)

Abbreviation: CARIES-OC

Country: England

Age group: 5 to 16 years

Respondents: Preschool children, older children and adolescents

Total items: 12

Dimensions: Unidimensional

Items: "hurts", "hard to eat some foods", "eating on one side", "food stuck", "kept awake", "annoyed", "hurt when brushing teeth", "eating carefully", "eating slowly", "feeling cross", "cried" and "hard to do schoolwork".

Cross-cultural adaptation: Table 7

The Caries Impacts and Experiences Questionnaire for Children (CARIES-QC) is the first self-reported questionnaire to involve children at all stages of its development. CARIES-OC is a caries-specific measure of quality of life with 12 items in one dimension (92). Diseasespecific instruments may be more capable of detecting subtle changes following treatment (93). Some studies have confirmed the impact of ECC on OHRQoL of young individuals. A more sensitive instrument may be useful in clarifying the relationship between non-severe active dental caries and OHROoL in children. Although specific, these instruments must be in accordance with the broad concept that defines OHRQoL. The global question of CARIES-QC was based on the question used in the Child Perceptions 
Questionnaire: "Overall, how healthy are your teeth?" (92).

Children participated in the early steps of items development for CARIES-QC. This method may have been helpful in reflecting language and impacts experienced by the target population, whose inclusion in the final stages of items development could have impaired content validity (92). CARIES-QC adopted the Consensus-based Standards for the Selection of Health Measurement Instruments (COSMIN) $(94,95)$.

Although CARIES-OC is not yet an established scale, due to its recent development, this instrument would be appropriate for use in cross-sectional and longitudinal investigations, to evaluate the association between dental caries experience and OHROoL (96). Future studies should assess the reliability and validity of the instrument with preschool children as a separate sample. To date, existing studies assess the quality of life of children between 5 and 16 years. The higher educational level and higher maturity of older children may impair an accurate evaluation of the reliability of CARIES-OC among younger children.

\begin{tabular}{|c|c|c|c|c|c|}
\hline \multicolumn{6}{|c|}{$\begin{array}{l}\text { Oral Health related Early Childhood Quality of Life } \\
\text { Authors/Year: Mathur et al., } 2014 \text { (98) }\end{array}$} \\
\hline \multirow{2}{*}{$\begin{array}{l}\text { Country - } \\
\text { Language }\end{array}$} & \multirow[b]{2}{*}{$\mathrm{N}$} & \multirow{2}{*}{$\begin{array}{c}\text { Female } \\
(\%)\end{array}$} & \multicolumn{3}{|c|}{ Measurement Proprieties } \\
\hline & & & Cronbach's $\alpha^{*}$ & $\begin{array}{l}\text { Test-retest } \\
\text { reliability }\end{array}$ & $\begin{array}{l}\text { Internal } \\
\text { structure }\end{array}$ \\
\hline $\begin{array}{l}\text { China - } \\
\text { Mandarin } \\
\text { Chinese (97) }\end{array}$ & 206 & 51.9 & 0.94 & $\begin{array}{c}\mathrm{n}=60 \\
\mathrm{t}=1 \text { month } \\
\mathrm{ICC}=0.83\end{array}$ & $\begin{array}{c}\text { CFA } \\
\text { RMSEA }=0.07 ; \\
\text { GFI }=0.92 ; \\
\text { CFI }=0.98 ; \\
\text { TLI }=0.96\end{array}$ \\
\hline $\begin{array}{l}\text { New Zeeland } \\
\text { - English (96) }\end{array}$ & 335 & 51.6 & 0.83 & $\begin{array}{c}\mathrm{n}=38 \\
\mathrm{t}=\mathrm{NR} \\
\mathrm{ICC}=0.80\end{array}$ & NR \\
\hline
\end{tabular}

*Cronbach's $\alpha$ for the global score. NR: non-reported. ICC: Intraclass Correlation Coefficient. CFA: Confirmatory Factor Analysis. CFI: Comparative Fit Index. GFI: Goodness-of-fit index. RMSEA: Root Mean Square Error of Approximation. TLI: Tucker-Lewis index.

Table 8. Descriptive and measurement properties of cross-cultural adaptations of OH- ECQOL

\begin{tabular}{lccccc}
\hline & & \multicolumn{3}{c}{ Measurement Proprieties } \\
\cline { 4 - 6 } $\begin{array}{l}\text { Country - } \\
\text { Language }\end{array}$ & $\mathrm{N}$ & $\begin{array}{c}\text { Female } \\
(\%)\end{array}$ & $\begin{array}{c}\text { Internal } \\
\text { Consistency } \\
(\text { Cronbach's } \alpha)^{*}\end{array}$ & $\begin{array}{c}\text { Test-retest } \\
\text { reliability }\end{array}$ & $\begin{array}{c}\text { Internal } \\
\text { structure }\end{array}$ \\
\hline $\begin{array}{l}\text { India - } \\
\text { Manipuri (99) }\end{array}$ & 300 & 46.7 & 0.84 & $\begin{array}{c}\mathrm{n}=20 \\
\mathrm{t}=14 \text { days } \\
\text { ICC }=0.94\end{array}$ & $\mathrm{NR}$ \\
\hline
\end{tabular}

${ }^{*}$ Cronbach's $\alpha$ for the global score. NR: non-reported. ICC: Intraclass Correlation Coefficient.
Abbreviation: $\mathrm{OH}-\mathrm{ECOOL}$

Country: India

Age group: 2-5-year-old children

Respondents: Parent/caregiver

Total items: 16

Dimensions: symptom, function, emotional, family/ social well-being and systemic well-being.

Cross-cultural adaptation: Table 8

The Oral Health Related Early Childhood Quality of Life $(\mathrm{OH}-\mathrm{ECOOL})$ is the first instrument to evaluate OHROoL of preschool children originally created to consider the social environment of a developing country. Their authors highlighted social and cultural characteristics of India that justify its development. Cultural beliefs often supersede logic and there are strong economic and literacy discrepancies within the Indian population. Moreover, parents/caregivers may give lower priority for child oral health when compared to other countries. The development of an instrument which takes culture, language (Hindi), sociodemographic and economic aspects of a population to account results in a construct validity fitted for the context of their country (98).

Most 16 items in $\mathrm{OH}-\mathrm{ECOOL}$ derive from CHO (Child Health Questionnaire), Infant Toddler Quality of Life Questionnaire (ITOOL), CPO, and ECOHIS. The language of the instrument is Hindi, while the other instruments have been developed in English (98). There is an incorrect perception that the international research community would not accept measures without an Englishlanguage version. Other poor and developing countries could follow India's example and create instruments fitted to their cultures. More studies in India should use $\mathrm{OH}-\mathrm{ECOOL}$ to provide deeper evaluation of its psychometric characteristics, and then, establish the scale as a gold-standard for OHROoL in the country.

\section{Child Oral Health Impact Profile - Preschool version}

Authors/Year: Ruff et al., 2017 (100)

Abbreviation: COHIP-PS

Country: United States of America

Age group: 2-5-year-old children

Respondents: Parent/caregiver

Total items: 11

Dimensions: functional well-being, social-emotional well-being, and self-image.

Cross-cultural adaptation: Table 9 
The Child Oral Health Impact Profile - Preschool version (COHIP-PS) is a proxy-reported instrument comprised by 11 items adapted from the Child Oral Health Impact Profile (COHIP), which is focused in the scholars group $(100,101)$. Both COHIP and COHIP-PS evaluate positive and negative perceptions of health and health outcomes (100). The COHIP-PS was the first validated instrument developed to assess OHRQoL in preschool children (2 to 5 years) using four groups: preschoolers with cleft lip and/or palate; those seeking speech therapy; those seeking routine paediatric dental care; and children from surrounding communities (100). This instrument use similar reasons of ECOHIS to justify the proxy-report approach $(5,18)$. Although the broad sample which was validated, psychometric properties suggest that the COHIP-PS may not show satisfactory reliability in patients without oral conditions. The COHIP-PS studies have to advance in their psychometric evidence, especially in the cross-cultural context. Besides, it is recommended to explore the impact of cleft severity, rather than cleft type, on OHROoL (99). A Chinese study cross-validated the COHIP-PS and created a web-based version (102).

\section{Future Perspectives for OHROoL Instruments}

A significant number of instruments to assess $\mathrm{OHROOL}$ of preschool children is available in literature. However, there are some psychometric, logistic and investigation approaches that still need to be incorporated into OHROoL measures to improve their effectiveness, reliability, comparability, and theoretical framework. Based on the limitations reported in literature and the experience of the authors in this field, some suggestions for future developments and adaptations of OHROoL instruments are highlighted:

Multidimensionality: Multidimensionality is an inherent feature of the broad concept of the Quality of Life construct. An internal structure which comprises a set of indicators sharing a single underlying factor (unidimensional) may inadequately simplify the OHROoL model. Unidimensional models violate the theoretical framework of the construct, threaten its validity and lead issues to model-data fit (103). OHROoL instruments must be developed or adapted in a theory-driven way which considers the multidimensionality that makes up the complex and complete notion of the subject (104).

Illiteracy: Socioeconomic status is related to educational level, oral health outcomes and OHRQoL. A higher prevalence of oral conditions enhances the need to evaluate OHROoL (105) an it is not surprising that most cross-cultural adaptations of OHROoL instruments take place in poor and developing countries $(46,48,71)$. However, the higher prevalence of illiteracy or low literacy in these countries could represent a barrier to the use of self-administered instruments (106). OHROoL instruments should be validated/adapted for these vulnerable populations using an interview structure. This approach would avoid the exclusion of illiterate participants.

Measurement invariance: Cross-cultural adaptations must present evidence of measurement invariance $(107,108)$. This method examines whether an instrument has the same psychometric properties across heterogeneous groups or over time (107). If measurement invariance is not tested in a cross-cultural adaptation, there is no assurance that the instrument is truly assessing an equivalent construct of OHRQoL. Likewise, researchers cannot safely conduct cross-cultural comparisons (108). Despite the relevance of measurement invariance, it is still not usually tested in cross-cultural adaptations in Dentistry. As far as we know, no OHRQoL comparisons should be inferred for different groups of preschool children, since there is no evidence of measurement invariance for any instrument in this field.

Short versions: Commonly, there are short-form versions with 8 to 20 items originated from long-forms OHROoL questionnaires with 30 to 50 items (109). Before developing a short-form version, researchers should consider whether a quick application of the instrument compensates the impact on its psychometric properties (i.e., lower reliability) (110). It should also be considered how quicker the new version will be when compared to the long form. What makes a questionnaire timeconsuming is not only the number of items, but also the subject, response scale, length of items, layout, and other operational issues. The number of items should not be the single criterion to justify a short-form questionnaire. Once the development of
Table 9. Descriptive and measurement properties of cross-cultural adaptations of COHIP-PS

\begin{tabular}{|c|c|c|c|c|c|}
\hline \multirow{2}{*}{$\begin{array}{l}\text { Country - } \\
\text { Language }\end{array}$} & \multirow{2}{*}{$\mathrm{N}$} & \multirow{2}{*}{$\begin{array}{c}\text { Female } \\
(\%)\end{array}$} & \multicolumn{3}{|c|}{ Measurement Proprieties } \\
\hline & & & Cronbach's $\alpha^{*}$ & $\begin{array}{l}\text { Test-retest } \\
\text { reliability }\end{array}$ & Internal structure \\
\hline $\begin{array}{l}\text { China - } \\
\text { Mandarin (102) }\end{array}$ & 260 & 46.9 & 0.903 & $\begin{array}{c}n=60 \\
t=14 \text { days } \\
I C C=0.86\end{array}$ & $\begin{array}{c}\text { CFA } \\
\text { CFI }=0.946 ; \text { TLI }=0.942 ; \\
\text { GFI }=0.927 ; \text { RMSEA }=0.075\end{array}$ \\
\hline
\end{tabular}

*Cronbach's $\alpha$ for the global score. ICC: Intraclass Correlation Coefficient. CFA: Confirmatory Factor Analysis. CFI: Comparative Fit Index. GFI: Goodness-of-fit index. RMSEA: Root Mean Square Error of Approximation. TLI: Tucker-Lewis index. 
the short form is decided, developers must consider that OHROoL is a broad construct, and its content validity should be maintained. It is crucial to be aware that shorter instruments are usually less sensitive for outcome measures (103).

Delimitations/Specifications: The development of an age group adequate questionnaire guarantees higher adequacy of vocabulary, cognitive level, life experiences, and inherent features of the group $(4,5,56)$. However, some questionnaires developed for a specific age group could be applied to a broader age range without significant issues in their ability to measure (57). Very age-specific questionnaires may limit their applicability and disturb clinical logistics. On contrary, condition- or treatmentspecific instruments should be more explored as long as the condition/treatment presents peculiarities for OHROoL, which could not be captured through general measures.

Self- and proxy-report: Although the SOHO-5 introduced the use of self-perception to score the impact of oral conditions in the OHRQoL of young children, this approach is not usual in the other instruments for the same age group. More studies should advance to investigate the influence of socioeconomic factors in the reliability of self-reports. Consequently, a strong base may support the relevance of this approach in preschool children, standardizing the methodology.

COSMIN: The Consensus-based Standards for the Selection of Health Measurement Instruments (COSMIN) checklist was developed in an international Delphi study aiming to provide tools for evidence-based instrument selection (available at http://www.cosmin.nl/). Most specific OHRQoL instruments were developed prior to the publication of the COSMIN checklist. Researchers and clinicians should use the COSMIN checklist in the selection of the best instrument for a given purpose in the wide range of scientific articles. COSMIN can be an important checklist to assess measurement properties and applicability of future instruments $(94,111)$.

\section{Final Considerations}

Although recent, the study field of OHROoL in preschool children has provided diverse instruments developed in holistic and multidisciplinary approaches. The present study did not have the intention to fulfil all the gaps in the measurement of OHRQoL in preschool children, but the key-points exposed showed the complexity of this construct in young children. The peculiarities of early-old ages, such as parental dependency and the process of social maturation, do not only represent survey challenges, but are also part of the reasons that justify surveys. The future is an unknown road and the understanding of obstacles may prevent unpleasant consequences. Therefore, clinicians and researchers should be aware of the relevance of the appropriate selection and use of instruments to measure OHROoL of preschool children. Meanwhile, the oral health science may progress in the psychometric assessment in two main ways. Firstly, reinforce the importance to check the properties of validated instruments in line with the latest evidence of psychometry, before their application. Secondly, advance in the development of new instruments based on the limitations of the available questionnaires.

\section{Resumo}

Qualidade de Vida Relacionada à Saúde Bucal (OVRSB) é um conceito que extrapola uma percepção exclusivamente clínica ao incluir questões funcionais, sociais, emocionais e ambientais. A avaliação da OVRSB representa uma abordagem holística para a pesquisa e prática clínica. 0 impacto negativo das condições bucais na QVRSB durante a infância pode refletir no desenvolvimento saudável, especialmente em um estágio da vida marcado pela maturação social e cognitiva. Instrumentos vêm sendo desenvolvidos e adaptados transculturalmente para avaliar o impacto das condições bucais na QVRSB de pré-escolares e seus familiares. Algumas caracteristicas distinguem esses instrumentos e influenciam na seleção, tais como: autorrelato ou relato proxy; condição genérica ou especifica; formas longas ou curtas, mais ou menos estabelecidos na literatura. Além disso, a base teórica, a avaliação do construto e a disponibilidade do instrumento também devem ser consideradas. A diversidade de instrumentos indica a evolução dos estudos em OVRSB, mas ainda há questões metodológicas que precisam ser avançadas em futuros desenvolvimentos ou adaptações desses instrumentos, seguindo as atuais evidências psicométricas. 0 presente estudo objetiva descrever as diferentes abordagens para avaliar a OVRSB de pré-escolares e discutir as perspectivas para futuros instrumentos.

\section{Acknowledgements}

Funding was provided by the National Council for Scientific and Technological Development (CNPq) and the study was financed in part by the Coordenação de Aperfeiçoamento de Pessoal de Nivel Superior Brazil (CAPES) - Finance Code 001. Moreover, this study was additionally supported by the Federal University of Minas Gerais (UFMG).

\section{References}

1. Sischo L, Broder HL. Oral Health-related Quality of Life. J Dent Res 2011;90:1264-1270.

2. Baker SR. Testing a conceptual model of oral health: a structural equation modeling approach. J Dent Res 2007;86:708-712.

3. Gomes MC, Clementino MA, Pinto-Sarmento TC de A, Martins CC, Granville-Garcia AF, Paiva SM. Association between parental guilt and oral health problems in preschool children: a hierarchical approach. BMC Public Health 2014;14:854.

4. Tsakos G, Blair Yl, Yusuf H, Wright W, Watt RG, Macpherson LMD. Developing a new self-reported scale of oral health outcomes for 5-year-old children (SOHO-5). Health Qual Life Outcomes 2012;10:62.

5. Pahel B, Rozier RG, Slade G. Parental perceptions of children's oral health: The Early Childhood Oral Health Impact Scale (ECOHIS). Health Qual Life Outcomes 2007;5:6.

6. Tsakos G, Blair YI, Yusuf H, Wright W, Watt RG, Macpherson LMD. Developing a new self-reported scale of oral health outcomes for 5-year-old children (SOH0-5). Health Qual Life Outcomes 2012;10:62.

7. Perazzo MF, Serra-Negra JM, Firmino RT, Pordeus IA, Martins-Júnior PA, Paiva SM. Patient-centered assessments: how can they be used in dental clinical trials? Braz Oral Res 2020.

8. Perazzo MF, Gomes MC, Neves ÉT, Martins CC, Paiva SM, Costa EMM de 
$B$, et al. Oral problems and quality of life of preschool children: selfreports of children and perception of parents/caregivers. Eur J Oral Sci 2017; 125:272-279

9. Higginson IJ, Carr AJ. Measuring quality of life: Using quality of life measures in the clinical setting. BMJ 2001;322:1297-1300.

10. Locker D, Jokovic A, Tompson B. Health-related quality of life of children aged 11 to 14 years with orofacial conditions. Cleft Palate Craniofac J 2005;42:260-266.

11. Filstrup SL, Briskie D, da Fonseca M, Lawrence L, Wandera A, Inglehart MR. Early childhood caries and quality of life: child and parent perspectives. Pediatr Dent 25:431-440.

12. Hassan $A$, Hassan M, Lenajwi A. Association of orthodontic treatment needs and oral health-related quality of life in Saudi children seeking orthodontic treatment. Patient Prefer Adherence 2014;8:1571-1579.

13. Scarpelli AC, Oliveira BH, Tesch FC, Leao AT, Pordeus IA, Paiva SM. Psychometric properties of the Brazilian version of the Early Childhood Oral Health Impact Scale (B-ECOHIS). BMC Oral Health 2011;11:19.

14. Martins-Júnior PA, Ramos-Jorge J, Martins Paiva $S$, Silva Marques LS, Ramos-Jorge ML. Validations of the Brazilian version of the Early Childhood Oral Health Impact Scale (ECOHIS). Cad Saude Publica 2012;28:367-374.

15. Bordoni N, Ciaravino 0, Zambrano O, Villena R, Beltran-Aguilar E, Squassi A. Early Childhood Oral Health Impact Scale (ECOHIS). Translation and validation in Spanish language. Acta Odontol Latinoam 2012;25:270-278.

16. Hashim AN, Yusof ZYM, Esa R. The Malay version of the Early Childhood Oral Health Impact Scale (Malay-ECOHIS): assessing validity and reliability. Health Qual Life Outcomes 2015;13:190.

17. Ortiz FR, Santos MD Dos, Landenberger T, Emmanuelli B, Agostini BA, Ardenghi TM. Comparison of Face-To-Face Interview and Telephone Methods of Administration on the Ecohis Scores. Braz Dent J 27:613618.

18. Ellert U, Ravens-Sieberer U, Erhart M, Kurth B-M. Determinants of agreement between self-reported and parent-assessed quality of life for children in Germany-results of the German Health Interview and Examination Survey for Children and Adolescents (KiGGS). Health Qual Life Outcomes 2011;9:102.

19. Rebok G, Riley A, Forrest C, Starfield B, Green B, Robertson J, et al. Elementary school-aged children's reports of their health: a cognitive interviewing study. Qual Life Res 2001;10:59-70.

20. Perazzo MF, Gomes MC, Neves ÉT, Martins CC, Paiva SM, GranvilleGarcia AF. Oral health-related quality of life and sense of coherence regarding the use of dental services by preschool children. Int J Paediatr Dent 2017;27:334-343.

21. de Alencar NA, Leão CS, Leão AT, Luiz RR, Fonseca-Gonçalves $A$, Maia LC. Sleep Bruxism and Anxiety Impacts in Quality of Life Related to Oral Health of Brazilian Children and their Families. J Clin Pediatr Dent 2017:41:179-185.

22. Ortiz FR, Tomazoni F, Oliveira MDM, Piovesan C, Mendes F, Ardenghi TM. Toothache, Associated factors, And its impact on oral healthrelated quality of life (OHRQoL) in preschool children. Braz Dent J 2014;25:546-553.

23. Vieira-Andrade RG, Martins-Junior $P A$, Correa-Faria $P$, Marques $L S$, Paiva SM, Ramos-Jorge ML. Impact of oral mucosal conditions on oral health-related quality of life in preschool children: a hierarchical approach. Int J Paediatr Dent 2015;25:117-126.

24. Onoriobe U, Rozier RG, Cantrell J, King RS. effects of enamel fluorosis and dental caries on quality of life. J Dent Res 2014;93:972-979.

25. Marques AL, Alencar NA de, Maia LC, Antonio AG. Quality of Life related to Eruption Hematoma in a Twenty Months Old Infant. J Contemp Dent Pract. 2015;16:763-767.

26. Abanto J, Carvalho TS, Mendes FM, Wanderley MT, Bonecker M, Raggio DP. Impact of oral diseases and disorders on oral health-related quality of life of preschool children. Community Dent Oral Epidemiol 2011;39:105-114.

27. Patel $\mathrm{N}$, Hodges $\mathrm{SJ}$, Hall $\mathrm{M}$, Benson $\mathrm{PE}$, Marshman $\mathrm{Z}$, Cunningham SJ. Development of the Malocclusion Impact Questionnaire (MIQ) to measure the oral health-related quality of life of young people with malocclusion: part 1 - qualitative inquiry J Orthod 2016:43:7-13.
28. Abanto J, Paiva SM, Sheiham A, Tsakos G, Mendes FM, Cordeschi T, et al. Changes in preschool children's OHRQoL after treatment of dental caries: responsiveness of the B-ECOHIS. Int J Paediatr Dent 2016;26:259-265.

29. Novaes TF, Pontes LRA, Freitas JG, Acosta CP, Andrade KCE, Guedes RS, et al. Responsiveness of the Early Childhood Oral Health Impact Scale (ECOHIS) is related to dental treatment complexity. Health Qual Life Outcomes 2017;15:182.

30. Lee GHM, McGrath C, Yiu CKY, King NM. Sensitivity and responsiveness of the Chinese ECOHIS to dental treatment under general anaesthesia. Community Dent Oral Epidemiol 2011;39:372-377.

31. Arrow P. Responsiveness and sensitivity of the early childhood oral health impact scale to primary dental care for early childhood caries. Community Dent Oral Epidemiol 2016;44:1-10

32. Li S, Malkinson S, Veronneau J, Allison PJ. Testing responsiveness to change for the early childhood oral health impact scale (ECOHIS). Community Dent Oral Epidemiol.2008;36:542-548.

33. Abanto J, Paiva SM, Sheiham A, Tsakos G, Mendes FM, Cordeschi T, et al. Changes in preschool children's OHRQoL after treatment of dental caries: responsiveness of the B-ECOHIS. Int J Paediatr Dent 2016;26:259-265.

34. Arrow P, Klobas E. Evaluation of the Early Childhood Oral Health Impact Scale in an Australian preschool child population. Aust Dent J 2015;60:375-381.

35. Li S, Veronneau J, Allison P. Validation of a French language version of the Early Childhood Oral Health Impact Scale (ECOHIS). Heal Qual Life Outcomes 2008;6.

36. Zaror C, Atala-Acevedo C, Espinoza-Espinoza G, Muñoz-Millán $P$, Muñoz S, Martínez-Zapata MJ, et al. Cross-cultural adaptation and psychometric evaluation of the early childhood oral health impact scale (ECOHIS) in chilean population. Health Qual Life Outcomes 2018;16:232.

37. Lee GHM, McGrath C, Yiu CKY, King NM. Translation and validation of a Chinese language version of the Early Childhood Oral Health Impact Scale (ECOHIS). Int J Paediatr Dent 2009;19:399-405

38. Díaz $S$, Mondol M, Peñate $A$, Puerta $G$, Boneckér $M$, Martins Paiva $S$, et al. Parental perceptions of impact of oral disorders on Colombian preschoolers' oral health-related quality of life. Acta Odontol Latinoam 2018;31:23-31.

39. Ghanghas M, Manjunath B, Kumar A, Shyam R, Phogat R, Panghal $V$ V Validation of the Hindi version of the early childhood oral health impact scale among 3-5-year-old preschool children in Rohtak city, Haryana. J Indian Soc Pedod Prev Dent 2019;37:333.

40. Jabarifar S-E, Golkari A, IJadi MH, Jafarzadeh M, Khadem P. Validation of a farsi version of the early childhood oral health impact scale (F-ECOHIS). BMC Oral Health 2010;10:4.

41. Jankauskienè B, Narbutaitè J, Kubilius R, Gleiznys A. Adaptation and validation of the early childhood oral health impact scale in Lithuania. Stomatologija 2012;14:108.

42. Nzomiwu CL, Sote EO, Oredugba FA. Translation and validation of the nigerian pidgin english version of the early childhood oral health impact scale (NAIJA ECOHIS). West Afr J Med 2018;35:102-108.

43. López Ramos RP, García Rupaya CR, Villena-Sarmiento R, Bordoni NE. Cross cultural adaptation and validation of the Early Childhood Health Impact Scale (ECOHIS) in Peruvian preschoolers. Acta Odontol Latinoam 2013:26:60-67.

44. Farsi NJ, El-Housseiny AA, Farsi DJ, Farsi NM. Validation of the arabic version of the early childhood oral health impact scale (ECOHIS). BMC Oral Health 2017;17:60.

45. Masumo R, Bardsen A, Mashoto K, Åstrøm AN. Child- and family impacts of infants' oral conditions in Tanzania and Uganda- a cross sectional study. BMC Res Notes. 2012;5:538.

46. Naidu R, Nunn J, Donnelly-Swift E. Oral health-related quality of life and early childhood caries among preschool children in Trinidad. BMC Oral Health. 2016;16:128.

47. Peker K, Uysal Ö, Bermek G. Cross-cultural adaptation and preliminary validation of the turkish version of the early childhood oral health impact scale among 5-6-year-old children. health qual life outcomes $2011 ; 9: 118$. 
48. Abanto J, Tsakos G, Paiva SM, Goursand D, Raggio DP, Bönecker M. Cross-cultural adaptation and psychometric properties of the Brazilian version of the scale of oral health outcomes for 5-year-old children (SOHO-5). Health Qual Life Outcomes. 2013;11:16.

49. Fernandes IB, Ramos-Jorge J, Ramos-Jorge $M L$, Bönecker $M$, Abanto J, Marques LS, et al. Correlation and comparative analysis of discriminative validity of the Scale of Oral Health Outcomes for Five-Year-Old Children (SOHO-5) and the Early Childhood Oral Health Impact Scale (ECOHIS) for dental caries. BMC Oral Health 2015;15:29.

50. Jokovic $A$, Locker $D$, Guyatt $G$. How well do parents know their children? Implications for proxy reporting of child health-related quality of life. Qual Life Res 2004;13:1297-1307.

51. Abanto J, Cordeschi T, Peters BG, Paiva SM, Bonecker M. Concordância entre os relatos do núcleo familiar em relação à qualidade de vida da criança. Rev Assoc Paul Cir Dent 2014;68:44-48.

52. Abreu-Placeres N, Garrido LE, Féliz-Matos LE. Cross-cultural validation of the Scale of Oral Health-Related outcomes for 5-year-old-children with a low-income sample from the Dominican Republic. J Int Soc Prev Community Dent 2017;7:84-89.

53. Gao SS, Chen KJ, Duangthip D, Chu CH, Lo ECM. Translation and validation of the Chinese version of the scale of oral health outcomes for 5-year-old children. Int Dent J. 2020;idj.12545.

54. Rachmawati YL, Pratiwi AN, Maharani DA. Cross-cultural adaptation and psychometric properties of the indonesia version of the scale of oral health outcomes for 5-Year-Old Children. J Int Soc Prev Community Dent 2017;7:75-81.

55. Asgari I, Kazemi E. Cross-Cultural Adaptation of Persian Version of Scale of Oral Health Outcomes for 5-Year-Old Children. J Dent (Tehran) 2017;14:48-54.

56. Jokovic A, Locker D, Stephens M, Kenny D, Tompson B, Guyatt G. Measuring parental perceptions of child oral health-related quality of life. J Public Health Dent 2003;63:67-72.

57. Foster Page LA, Boyd D, Thomson WM. Do we need more than one Child Perceptions Questionnaire for children and adolescents? BMC Oral Health 2013;13:26.

58. Thomson WM, Foster Page LA, Malden PE, Gaynor WN, Nordin N. Comparison of the ECOHIS and short-form P-CPO and FIS scales. Health Qual Life Outcomes 2014;12:36.

59. Gradella CMF, Bernabé E, Bönecker M, Oliveira LB. Caries prevalence and severity, and quality of life in Brazilian 2- to 4-year-old children. Community Dent Oral Epidemiol 2011;39:498-504.

60. Thomson WM, Foster Page LA, Gaynor WN, Malden PE. Short-form versions of the Parental-Caregivers Perceptions Questionnaire and the Family Impact Scale. Community Dent Oral Epidemiol 2013;41:441450.

61. Petrides K V. Psychometric properties of the Trait Emotional Intelligence Questionnaire (TEIQue). In: The Springer series on human exceptionality. New York: Springer;2009.p.85-101.

62. Goursand D, Ferreira MC, Pordeus IA, Mingoti SA, Veiga RT, Paiva SM. Development of a short form of the brazilian parental-caregiver perceptions questionnaire using exploratory and confirmatory factor analysis. Qual Life Res 2013;22:393-402.

63. Al-Riyami IA, Thomson WM, Al-Harthi LS. Testing the arabic short form versions of the parental-caregivers perceptions questionnaire and the family impact scale in oman. Saudi Dent J 2016;28:31-35.

64. Kumar S, Kroon J, Lalloo R, Johnson NW. Validity and reliability of short forms of parental-caregiver perception and family impact scale in a Telugu speaking population of India. Health Qual Life Outcomes 2016;14:34.

65. Barbosa T de S, Gavião MBD. Validation of the parental-caregiver perceptions questionnaire: agreement between parental and child reports. J Public Health Dent 2015;75:255-264.

66. Malden PE, Thomson WM, Jokovic A, Locker D. Changes in parentassessed oral health-related quality of life among young children following dental treatment under general anaesthetic. Community Dent Oral Epidemiol 2008;36:108-117.

67. de Souza MC, Harrison M, Marshman Z. Oral health-related quality of life following dental treatment under general anaesthesia for early childhood caries - a UK-based study. Int J Paediatr Dent 2017;27:30-36.
68. Goursand D, Paiva SM, Zarzar PM, Pordeus IA, Grochowski R, Allison PJ. Measuring parental-caregiver perceptions of child oral health-related quality of life: psychometric properties of the Brazilian version of the P-CPO. Braz Dent J 2009;20:169-174.

69. McGrath C, Pang Hn, Lo Ecm, King Nm, Hägg U, Samman N. Translation and evaluation of a Chinese version of the Child Oral Health-related Quality of Life measure. Int J Paediatr Dent 2008;18:267-274.

70. Razanamihaja N, Boy-Lefèvre $M-L$, Jordan L, Tapiro L, Berdal A, de la Dure-Molla $\mathrm{M}$, et al. Parental-Caregivers Perceptions Questionnaire (P-CPO): translation and evaluation of psychometric properties of the French version of the questionnaire. BMC Oral Health 2018;18:211.

71. Albites U, Abanto J, Bonecker M, Paiva S, Aguilar-Galvez D, Castillo J. Parental-caregiver perceptions of child oral health-related quality of life (P-CPQ): Psychometric properties for the Peruvian Spanish language. Med Oral Patol Oral y Cir Bucal 2014;220-224.

72. Dimberg L, Lennartsson B, Bondemark L, Arnrup K. Validity and reliability of the Swedish versions of the short-form Child Perceptions Questionnaire 11-14 and Parental Perceptions Questionnaire. Acta Odontol Scand 2019;77:630-635.

73. Marshman Z, Rodd H, Stem M, Mitchell C, Robinson PG. Evaluation of the Parental Perceptions Questionnaire, a component of the COHOoL, for use in the UK. Community Dent Health 2007;24:198-204.

74. Wood WT, Firestone AR, Beck FM, Lenk MD, Jokovic A. Reliability and validity of child perceptions questionnaire and parent perceptions questionnaire for oral-health-related quality of life in American children ages 11-14. Am J Orthod Dentofac Orthop. 2006;129:710.

75. Steele MM, Steele RG, Varni JW. Reliability and Validity of the PedsQLTM oral health scale: measuring the relationship between Child Oral Health and Health-Related Quality of Life. Child Heal Care 2009;38:228-244.

76. Varni JW, Seid M, Kurtin PS. PedsQL 4.0: reliability and validity of the Pediatric Quality of Life Inventory version 4.0 generic core scales in healthy and patient populations. Med Care 2001;39:800-812.

77. Chan KS, Mangione-Smith R, Burwinkle TM, Rosen M, Varni JW. The PedsQL: reliability and validity of the short-form generic core scales and Asthma Module. Med Care 2005;43:256-265.

78. Uzark K, Jones K, Burwinkle TM, Varni JW. The Pediatric Quality of Life InventoryTM in children with heart disease. Prog Pediatr Cardiol 2003;18:141-149.

79. Varni JW, Burwinkle TM, Jacobs JR, Gottschalk M, Kaufman F, Jones $\mathrm{KL}$. The pedsql in type 1 and type 2 diabetes: reliability and validity of the pediatric quality of life inventory generic core scales and type 1 diabetes module. Diabetes Care 2003;26:631-637.

80. Varni JW, Burwinkle TM, Katz ER, Meeske K, Dickinson P. The PedsOL in pediatric cancer: reliability and validity of the Pediatric Quality of Life Inventory Generic Core Scales, Multidimensional Fatigue Scale, and Cancer Module. Cancer. 2002;94:2090-2106.

81. Varni JW, Burwinkle TM, Rapoff MA, Kamps JL, Olson N. The Pedsql in pediatric asthma: reliability and validity of the pediatric quality of life inventory generic core scales and asthma module. J Behav Med 2004;27:297-318.

82. Varni JW, Burwinkle TM, Berrin SJ, Sherman SA, Artavia K, Malcarne $V L$, et al. The PedsQL in pediatric cerebral palsy: reliability, validity, and sensitivity of the generic core scales and cerebral palsy module. Dev Med Child Neurol 2006;48:442-449.

83. Du RY, McGrath C, Yiu CKY, King NM. Health- and oral health-related quality of life among preschool children with cerebral palsy. Qual Life Res 2010;19:1367-1371.

84. Broder HL, Norman RG, Sischo L, Wilson-Genderson M. Evaluation of the similarities and differences in response patterns to the Pediatric quality of life inventory and the child oral health impact scores among youth with cleft. Qual Life Res 2014;23:339-347.

85. Pakpour AH, Yekaninejad MS, Zarei F, Hashemi F, Steele MM, Varni JW. The PedsQLTM Oral Health Scale in Iranian children: reliability and validity. Int J Paediatr Dent 2011;21:342-352.

86. Bendo CB, Paiva SM, Viegas CM, Vale MP, Varni JW. The PedsQLTM Oral health scale: feasibility, reliability and validity of the Brazilian portuguese version. Health Qual Life Outcomes 2012;10:42.

87. Atala-Acevedo C, Zaror C, Espinoza-Espinoza G, Muñoz-Millán P, 
Muñoz S, Martínez-Zapata MJ, et al. Adaptation and validation of the PEDSOLTM oral health scale for toddlers in Chilean population. BMC Oral Health 2020;20:6.

88. Huntington NL, Spetter D, Jones JA, Rich SE, Garcia RI, Spiro A. Development and validation of a measure of pediatric oral healthrelated quality of life: the POQL. J Public Health Dent 2011;71:185-193.

89. Yazıcıoglu I, Jones J, Dogan C, Rich S, Garcia RI. Validity and reliability of a Turkish pediatric oral health-related quality of life measure. Eur Oral Res 2018;52:25-32.

90. Braun PA, Lind KE, Henderson WG, Brega AG, Quissell DO, Albino J. Validation of a pediatric oral health-related quality of life scale in Navajo children. Qual Life Res 2015;24:231-239.

91. Yazicioglu I, Jones JA, Cortés D, Rich S, Garcia R. Hispanic parents' reading language preference and pediatric oral health-related quality of life. J Public Health Dent 2013;73:329-338.

92. Gilchrist F, Rodd H, Deery C, Marshman Z. Assessment of the quality of measures of child oral health-related quality of life. BMC Oral Health 2014; $14: 40$.

93. U.S. Department of health and human services FDA center for drug evaluation and research, U.S. department of health and human services FDA center for biologics evaluation and research, U.S. department of health and human services FDA center for devices and radiological health. Guidance for industry: patient-reported outcome measures: use in medical product development to support labeling claims: draft guidance. Health Qual Life Outcomes 2006;4:79.

94. Paiva SM, Perazzo M de F, Ortiz FR, Pordeus IA, Martins-Júnior PA. How to select a questionnaire with a good methodological quality? Braz Dent J 2018;29:3-6.

95. Mokkink LB, Terwee CB, Patrick DL, Alonso J, Stratford PW, Knol DL, et al. The COSMIN checklist for assessing the methodological quality of studies on measurement properties of health status measurement instruments: an international Delphi study. Qual Life Res 2010;19:539549.

96. Foster Page L, Gilchrist F, Broder H, Clark E, Thomson W. A Comparison of three child Ohrqol measures. Dent J 2019;7:19.

97. He S, Wang J. Validation of the Chinese version of the caries impacts and experiences questionnaire for children (CARIES-QC). Int J Paediatr Dent 2020;30:50-56.

98. Dhillon J, Logani A, Agarwal R, Mathur V. Development and validation of oral health-related early childhood quality of life tool for North Indian preschool children. Indian J Dent Res 2014;25:559.

99. Dharmani CK, Dhillon J, Mathur V. Validation of Manipuri version of oral health-related early childhood quality-of-life tool for preschool children. Indian J Dent Res 2019;30:742.
100. Ruff RR, Sischo L, Chinn CH, Broder HL. Development and validation of the Child Oral Health Impact Profile - Preschool version. Community Dent Health 2017;34:176-182.

101. Broder HL, McGrath C, Cisneros GJ. Questionnaire development: face validity and item impact testing of the Child Oral Health Impact Profile. Community Dent Oral Epidemiol 2007;35:8-19.

102. He S, Wang J. Development and validation of a web-based version of the child oral health impact profile - Preschool version. Int J Paediatr Dent 2020;12695.

103. Kose IA, Demirtasli NC. Comparison of unidimensional and multidimensional models based on item response theory in terms of both variables of test length and sample size. Procedia - Soc Behav Sci 2012;46:135-140.

104. Santos JB, Brito LAL. Toward a subjective measurement model for firm performance. BAR - Brazilian Adm Rev 2012;9:95-117.

105. Perazzo MF, Gomes MC, Neves ÉT, Martins CC, Paiva SM, GranvilleGarcia AF. Oral health-related quality of life and sense of coherence regarding the use of dental services by preschool children. Int J Paediatr Dent 2017;27:334-343.

106. Educational, United Nations Scientific and Cultural Organization - Institute for Statistics. Literacy rates continue to rise from one generation to the next. Unesco 2017:1-13.

107. Chen FF. Sensitivity of goodness of fit indexes to lack of measurement invariance. Struct Equ Model A Multidiscip J 2007;14:464-504.

108. Ziegler M, Bensch D. Lost in Translation: Thoughts Regarding the Translation of Existing Psychological Measures Into Other Languages. Eur J Psychol Assess. 2013;29:81-83.

109. Zaror C, Pardo $Y$, Espinoza-Espinoza G, Pont A, Muñoz-Millán P, Martinez-Zapata MJ, et al. Assessing oral health-related quality of life in children and adolescents: a systematic review and standardized comparison of available instruments. Clin Oral Investig 2019;23:65-79.

110. Keszei AP, Novak M, Streiner DL. Introduction to health measurement scales. J Psychosom Res 2010;68:319-323.

111. Mokkink LB, Terwee CB, Patrick DL, Alonso J, Stratford PW, Knol DL, et al. The COSMIN study reached international consensus on taxonomy, terminology, and definitions of measurement properties for healthrelated patient-reported outcomes. J Clin Epidemiol 2010;63:737-745.

Received July 29, 2020 Accepted August 14, 2020 